\title{
Partisipasi dan Persepsi Masyarakat desa Cinunuk Dalam PengelolaAn SAMPah
}

\section{${ }^{1}$ Teguh Husodo, ${ }^{2}$ Indri Wulandari, ${ }^{3}$ Erri Noviar Megantara, ${ }^{4}$ Sya Sya Shanida, ${ }^{5}$ Dwiki Danang Kuncoro, ${ }^{6}$ Nining Ratningsih}

\author{
1,2,3,6 Departemen Biologi, Fakultas Matematika dan Ilmu Pengetahuan Alam, Universitas Padjadjaran, \\ Jawa Barat, Indonesia. ${ }^{1,2,3}$ Program Pascasarjana Ilmu Lingkungan, Universitas Padjadjaran, Jawa \\ Barat, Indonesia. ${ }^{1,2,3,4,5}$ Center of Environment and Sustainable Science, Universitas Padjadjaran, Jawa \\ Barat, Indonesia. \\ email: 't.husodo@unpad.ac.id
}

\begin{abstract}
Community can participate in waste management through reducing waste, sorting waste, disposing of waste in its place, and reuse. This study aimed to determine community participation and factors influencing community participation in waste management, Cinunuk Village. Quantitative and qualitative methods were applied in this study, using a questionnaire, literature study, and direct observation. Respondents were determined by proportional random sampling. Discriminant analysis was applied in this study. The results show that reuse activities are still challenging to do in a village environment to minimize waste generation volume. The entire community has participated in every type of waste management activity. Where on average, the community actively participates in waste disposal activities (55\%). Meanwhile, in reduce, waste sorting and reuse activities, participation tends to be passive. The factors that distinguish the formation of active and passive community participation in Cinunuk Village are perception, experience, communication, and facilities. The classification of participation inoowaste management activities produces different factors.
\end{abstract}

Keywords: Community Participation, Waste, Waste Management

\begin{abstract}
Abstrak. Masyarakat dapat berpartisipasi dalam pengelolaan sampah melalui kegiatan reduce, memilah sampah, membuang sampah pada tempatnya, dan reuse. Tujuan dari penelitian ini adalah untuk mengetahui partisipasi masyarakat dan faktor yang berpengaruh terhadap partisipasi masyarakat dalam pengelolaan sampah di Desa Cinunuk. Metode kuantitatif dan kualitatif diaplikasikan pada studi ini, menggunakan kuesioner, studi literatur, dan observasi langsung. Pemilihan responden dilakukan secara proporsional random sampling. Analisis diskriminan diaplikasikan pada studi ini. Hasil menunjukan bahwa kegiatan reuse masih sulit dilakukan di lingkungan desa untuk meminimalisasi volume timbulan sampah. Seluruh masyarakat telah berpatisipasi dalam setiap jenis kegiatan pengelolaan sampah. Dimana rata-rata masyarakat berpartisipasi aktif dalam kegiatan membuang sampah (55\%). Sedangkan pada kegiatan reduce, memilah sampah dan kegiatan reuse, partisipasi masih cenderung pasif. Faktor yang membedakan terbentuknya partisipasi masyarakat secara aktif dan pasif dalam pengelolaan sampah di Desa Cinunuk adalah faktor persepsi, pengalaman, komunikasi dan sarana. Klasifikasi partisipasi masyarakat dalam kegiatan pengelolaan sampah menghasilkan faktor yang berbeda.
\end{abstract}

Kata Kunci: Cinunuk, Partisipasi Masyarakat, Pengelolaan Sampah

\section{Pendahuluan}

Sampah akan menjadi kendala lingkungan ketika tidak dikelola dengan baik dan berdampak merugikan bagi lingkungan sekitar. Menurut (Rejeki, dkk., 2016) sampah merupakan material sisa yang tidak diinginkan setelah berakhirnya suatu proses 
pemanfaatan/pemakaian. Sampah terdiri dari zat kimia, fisik, maupun biologis atau makhluk hidup yang sudah tidak memiliki nilai guna dan bersifat merusak. Sampah dapat berbentuk padat, cair, maupun gas. Materi cair dan gas menjadi emisi, bila dikaitkan dengan polusi. Sisa materi yang berbaur pada lingkungan air, udara, maupun tanah, maka kualitas lingkungan akan mengalami penurunan. Timbulnya sampah ke lingkungan dikenal dengan pencemaran lingkungan.

Menurut Suprapto (2005) sampah berpotensi berbahaya bagi kesehatan. Selain itu, Suprapto menambahkan dampak dari pengelolaan sampah yang tidak baik, seperti membuang sampah tidak pada tempatnya dapat menimbulkan masalah pencemaran, seperti pencemaran tanah, air, dan udara. Pencemaran tersebut akan mengganggu keseimbangan ekosistem seperti banjir dan mengganggu kenyaman dan keindahan (penurunan nilai estetika).

Di desa, masyarakat merupakan sumber potensial timbulnya sampah setiap harinya. Beberapa hasil kajian, rata-rata besarnya limbah padat (sampah) di masyarakat Indonesia menghasilkan $0,5 \mathrm{~kg}-0,7 \mathrm{~kg}$ limbah padat setiap hari. Lozano dan Valles (2007) dalam Fandoko \& Anityasari (2012) bahwa dampak lingkungan seperti air, listrik, material, sampah, pendingin ruangan, pencahayaan, dan transportasi dari pemukiman termasuk perguruan tinggi setara dampak lingkungan dari industri karena memiliki dampak terhadap kualitas lingkungan.

Secara administratif, Desa Cinunuk memiliki luas wilayah \pm 480,925 ha, terbagi menjadi enam wilayah Dusun, 29 RW, dan 195 RT dengan jumlah penduduk Desa Cinunuk sebanyak 51.134 jiwa dan jumlah Kepala Keluarga sebanyak 15.562 KK.
Mata pencaharian utama penduduk Desa Cinunuk adalah Buruh sejumlah 12.768 jiwa, disusul dengan PNS (NonMedis) sejumlah 5.214 jiwa, dan Wiraswasta sejumlah 4.622 jiwa (Pemerintah Desa Cinunuk, 2021). Mayoritas penduduk Desa Cinunuk beragama Islam dengan total 43.825 jiwa. Seluruh warga masyarakat adalah potensial sebagai sumber penghasil sampah di lingkungannya pada tingkat RW dan RT. Kecenderungan peningkatan volume sampah di lingkungan masyarakat Desa Cinunuk terus meningkat setiap tahunnya, hal tersebut dikarenakan peningkatan jumlah populasi yang mencapai angka sekitar $2,5 \%$ setiap tahunnya, juga ada peningkatan jumlah penduduk pendatang.

Seiring waktu, timbunan sampah terus meningkat, ditambah peningkatan pertumbuhan penduduk dan gaya hidup serta kapasitas pelayanan kebersihan yang semakin terbatas menjadikan suatu permasalahan yang harus dihadapi (Amaranti, et al., 2016). Tabel 1 menampilkan prediksi peningkatan jumlah sampah yang dihasilkan Desa Cinunuk.

Tabel 1.

Perkiraan Total Penduduk dan Volume Sampah Tahun 2018-2022

\begin{tabular}{ccccc}
\hline No & Tahun & $\begin{array}{c}\text { Jumlah } \\
\text { Penduduk } \\
\text { (Tahun/Jiwa) }\end{array}$ & $\begin{array}{c}\text { Volume } \\
\text { Sampah } \\
\text { (Kg/Tahun) }\end{array}$ & $\begin{array}{c}\text { Volume } \\
\text { Sampah } \\
\text { (Ton/ } \\
\text { Tahun) }\end{array}$ \\
\hline 1 & 2018 & $51.134,00$ & 13.064 .737 & 13.065 \\
\hline 2 & 2019 & $52.412,35$ & 13.391 .355 & 13.391 \\
\hline 3 & 2020 & $53.722,66$ & 13.726 .139 & 13.726 \\
\hline 4 & 2021 & $55.065,73$ & 14.069 .293 & 14.069 \\
\hline 5 & 2022 & $56.442,37$ & 14.421 .025 & 14.421 \\
\hline
\end{tabular}

Keterangan: Laju peningkatan jumlah penduduk adalah $2,5 \%$ pertahun dan volume sampah yang diproduksi mengacu kepada prediksi volume sampah: sudah dihitung berdasarkan Keputusan Menteri Pemukiman dan 
Prasarana Wilayah No. 534/KPTS/M/ 2001.

Berbagai pendapat menjelaskan bahwa mekanisme pengelolaan sampah erat hubungannya dengan kemampuan pelayanan publik, demikian pula dengan pelayanan pengelolaan sampah di Desa Cinunuk, tidak semata-mata menjadi tanggung jawab apartur desa, namun memerlukan pula dukungan dan peran serta warga agar kegiatan pelayanan dapat berjalan optimal dan efektif. Masyarakat sebagai sumber penghasil sampah terbesar seharusnya dapat mendukung dan ikut serta mengelola sampah yang dihasilkannya. Namun pada kenyataanya masih terlihat sampah yang berserakan disekitar lingkungan seperti taman RT/RW, selokan, area umum, dan lahan-lahan kosong. Meskipun pada beberapa daerah dilingkungan $\mathrm{RT} / \mathrm{RW}$ telah terdapat upaya masyarakat secara swadaya untuk melakukan pengelolaan, seperti tersedianya tempat sampah yang terpilah (organik dan non organik) di beberapa tempat, namun pada faktanya masih banyak ditemukan tumpukan sampah tersebut tetap tercampur.

Untuk mengetahui faktor yang berpengaruh dalam tingkat partisipasi masyarakat tersebut perlu dilakukan suatu penelitian lanjut yang mengkaji faktor internal seperti persepsi, pengetahuan, pengalaman, dan faktor eksternal meliputi komunikasi dan sarana. Beberapa peneliti seperti yang Sarinen dalam Harihanto (2004) bahwa persepsi memiliki kaitan dengan faktor peran serta masyarakat, faktor lain yang berpengaruh terhadap partisipasi yaitu pengetahuan dan pengalaman dari masyarakat (Saribanon, et al., 2008, sarana (Ife \& Tesoriero, 2008); serta akses atas informasi atau komunikasi (Maulina, 2012). Berdasarkan uraian tersebut, maka penelitian mengenai partisipasi masyarakat dalam pengelolaan sampah di sekitar lingkungan tempat tinggal dan faktor yang mempengaruhi terhadap partisipasi masyarakat dalam pengelolaan sampah perlu dilakukan agar diketahui faktor-faktor yang mempengaruhi sebagai hasil kajian dapat dipergunakan sebagai bagian pengelolaan sampah pada masa akan datang.

Fokus kajian pengelolaan sampah yang dilakukan di lingkungan masyarakat Desa Cinunuk dibatasi pada pengurangan sampah (reduce), pemilahan sampah, kegiatan membuang sampah pada tempatnya, dan penggunaan ulang sampah (reuse). Tujuan penelitian dimaksudkan untuk mengetahui sejauh mana partisipasi masyarakat dalam mengelola sampah serta faktor-faktor yang mempengaruhi aktivitas partisipasi masyarakat dalam mengelola sampah di lingkungan tempat tinggalnya. Kajian partisipasi masyarakat terhadap pengelolaan sampah ini menjadi penting, diharapkan dari hasil penelitian mendapatkan informasi mengenai keterbatasan masyarakat dalam pengelolaan sampah, selanjutnya dapat dijadikan saran dasar pengelolaan sampah yang lebih baik di masa mendatang.

\section{Metode Ilmiah}

Waktu dan Lokasi. Studi dilakukan dari Oktober s/d November 2019. Lokasi penelitian dilakukan secara purposive, yaitu masyarakat pada sepuluh (10) RW Desa Cinunuk.

Metode Pengumpulan Data. Kegiatan penelitian merupakan penelitian terintegrasi dengan kegiatan pengabdian kepada masyarakat KKN Tematik Citarum Harum di Kabupaten Bandung dan Kabupaten Sumedang. Desa Cinunuk adalah salah satu desa yang terpilih. Metode penelitian mengunakan metode mixed methode atau kombinasi metode. Sampel yang diambil dibatasi hanya pada masyarakat 
dengan status kepala keluarga, Ibu rumah tangga, kader posyandu, kader lingkungan dan tokoh lembaga masyarakat tingkat RW. Sampel yang diambil ditetapkan sebanyak 100 responden dengan proporsi jumlah populasi penduduk pada setiap RW.

Responden ditentukan dengan pendekatan proporsional random sampling pada setiap populasi RW dengan ukuran sampling menurut formula Sevilla et. al., (1960). Kuesioner diselesaikan dalam kurun waktu kurang dari satu bulan bersamaan dengan observasi selama kegiatan KKN di Desa Cinunuk. Data kuesioner dengan teknik pengumpulan data terukur menggunakan Skala Likert.

Metode Analisis Data. Data hasil kuesioner diinput, dirapihkan, dan di analisis. Hasil data studi ditampilkan dalam bentuk tabulasi data, sedangkan data mengenai faktor-faktor yang memengaruhi suatu partisipasi masyarakat dilakukan tabulasi data, kemudian dianalisis secara diskriminan. Menurut Ghozali (2016) bahwa analisis diskriminan merupakan bentuk regresi dengan varibel terikat non-metrik atau kategori. Pada studi ini, akan menggunakan analisis diskriminan untuk dua kelompok/dua kategori dimana variabel terikat dijadikan dua kategori, yaitu partisipasi aktif dan partisipasi pasif. Kemudian, hasilnya dianalisis secara deskriptif untuk menggambarkan dan menjelaskan olahan data yang dihasilkan.

\section{Hasil dan Pembahasan}

\section{Partisipasi Masyarakat dalam Mengurangi Sampah (Reduce)}

Partisipasi dalam kegiatan mengurangi sampah (reduce) yang dilakukan oleh 100 responden masyarakat seperti yang disajikan pada Tabel 2 diperoleh bahwa ketiga upaya kegiatan mengurangi sampah (reduce) terlihat adanya perbedaan partisipasi masyarakat dalam mengurangi sampah, yaitu partisipasi masyarakat lebih banyak mengurangi sampah organik dari pada berpartisipasi mengurangi sampah anorganik, termasuk upaya mengurangi sampah padat yang masih dapat dipergunakan ulang.

Tabel 2.

Partisipasi Masyarakat dalam Kegiatan Reduce

\begin{tabular}{|c|c|c|c|}
\hline \multicolumn{4}{|c|}{ Reduce } \\
\hline No & Pernyataan & $\begin{array}{c}\text { Partisipasi } \\
\text { dalam } \\
\text { Reduce } \\
\end{array}$ & $\begin{array}{l}\text { Respon- } \\
\text { den (\%) }\end{array}$ \\
\hline \multirow[t]{3}{*}{1} & \multirow{3}{*}{$\begin{array}{l}\text { Menghabiskan } \\
\text { setiap makanan } \\
\text { dan jajanan } \\
\text { yang di beli di } \\
\text { kampus }\end{array}$} & Aktif & 54 \\
\hline & & Pasif & 46 \\
\hline & & Jumlah & 100 \\
\hline \multirow[t]{3}{*}{2} & \multirow{3}{*}{$\begin{array}{l}\text { Membawa } \\
\text { botol minum } \\
\text { sendiri ke } \\
\text { kampus }\end{array}$} & Aktif & 38 \\
\hline & & Pasif & 62 \\
\hline & & Jumlah & 100 \\
\hline \multirow[t]{3}{*}{3} & \multirow{3}{*}{$\begin{array}{l}\text { Memfotokopi } \\
\text { setiap bahan } \\
\text { kuliah yang } \\
\text { diberikan dalam } \\
\text { bentuk hard } \\
\text { file, dari pada } \\
\text { mengkopi } \\
\text { berbentuk soft } \\
\text { file }\end{array}$} & Aktif & 54 \\
\hline & & Pasif & 46 \\
\hline & & Jumlah & 100 \\
\hline
\end{tabular}

Dapat dilihat pada Tabel 2, bahwa partisipasi masyarakat dalam mengurangi sampah kemasan botol plastik dan kertas masih tergolong pasif. Alfiandra (2009) menyatakan bahwa reduce sampah merupakan suatu usaha pengurangan timbunan sampah di lingkungan sumber sampah, bahkan usaha tersebut dapat dilakukan dari awal sebelum sampah tersebut dihasilkan.

Upaya lain yang dapat dilakukan untuk mengurangi sampah dapat dilakukan dengan menggunakan kertas bekas dengan sisi halaman kosong sebagai bahan fotokopi bahan kuliah. Kumpulan kertas bekas tersebut dapat dijadikan sebagai buku catatan untuk perkuliahan dan praktikum. Selain itu, membangun sarana khusus refill minuman dapat menjadi ketertarikan 
masyarakat untuk melakukan refill minuman.

\section{Partisipasi Masyarakat dalam Memilah Sampah}

Menurut Budiasih (2010) peningkatan jumlah volume sampah akan menjadi hal yang serius ketika sampah itu bercampur aduk. Penting dilakukannya pemilahan sampah untuk mengetahui dan memisahkan sampah yang dapat dimanfaatkan (Budiasih, 2010). Pada Tabel 3, menunjukkan partisipasi masyarakat dalam memilah sampah cenderung belum berpartisipasi secara aktif.

Tabel 3.

Partisipasi Masyarakat dalam Kegiatan Memilah Sampah

\begin{tabular}{cllc}
\hline No & Pernyataan & $\begin{array}{l}\text { Partisi- } \\
\text { pasi }\end{array}$ & $\begin{array}{c}\text { Responden } \\
(\mathbf{\%})\end{array}$ \\
\hline 1 & \begin{tabular}{l} 
Tidak \\
memilah \\
sampah, \\
walau tersedia \\
tempat \\
\cline { 2 - 3 }
\end{tabular} & Aktif & 31 \\
\cline { 2 - 3 } & Pasif & 69 \\
\hline
\end{tabular}

Beberapa alasan yang dikemukakan tidak memilah sampahnya, diantaranya masyarakat menganggap memilah sampah merupakan hal yang tidak efektif karena sampah akan disatukan lagi oleh petugas kebersihan dalam proses pengangkutan sampah. Beberapa masyarakat lain menjawab karena tidak tersedianya tempat sampah di lingkungan, sementara yang melakukan pemilahan sampah ataupun terdapat tempat pilah sampah, tidak dibagi menjadi organik dan anorganik. Sarana atau tempat sampah pilah menjadi hal yang perlu dalam mendukung pemilahan sampah. Pemilahan sampah yang dilakukan di Tempat Pembuangan Akhir (TPA) memerlukan sarana dan prasana yang memadai, serta memakan waktu dalam pemilahannya (Budiasih, 2010). Menurut Damanhuri dan Padma (2010), penanganan sampah dengan pemilahan jenis sampah dilakukan untuk mempermudah dalam melakukan berbagai tahap pengolahan sampah, termasuk daur ulang sampah.

Salah satu usaha yang dapat dilakukan untuk menarik minat masyarakat dalam memilah sampah, seperti memasang papan/poster informatif yang menarik sekitar tempat sampah. Selain itu, menjalin kerjasama dengan tokoh masyarakat dalam memberikan contoh praktik pemilahan sampah di lingkungan masyarakat.

\section{Partisipasi Masyarakat terkait Aktivitas Pembuangan Sampah}

Selain memilah sampah, membuang sampah pada tempatnya merupakan kegiatan paling sederhana dalam penanganan sampah. Dari kedua upaya membuang sampah pada tempatnya, dapat diketahui bahwa masyarakat aktif dalam membuang sampah. Namun, sebanyak 41\% masyarakat yang belum ikut serta secara aktif dalam membuang sampah pada tempatnya.

Morgan (2009) dalam Fadhilah, dkk. (2011) mengungkapkan bahwa masyarakat mudah untuk membuang sampah dimana-mana. Seringkali masyarakat tidak berpikir panjang dampak akhir dari sampah-sampah tersebut. Setiap sumber penghasil sampah, seharusnya dapat membuang sampah pada tempat yang telah disediakan (Tabel 4)

Tabel 4.

Partisipasi Masyarakat dalam Membuang

Sampah

\begin{tabular}{|c|c|c|c|}
\hline No & Pernyataan & Partisipasi & $\begin{array}{l}\text { Respon- } \\
\text { den }(\%)\end{array}$ \\
\hline \multirow[t]{3}{*}{1} & \multirow{3}{*}{$\begin{array}{l}\text { Membuang } \\
\text { sampah plastik } \\
\text { jajanan di mana } \\
\text { saja }\end{array}$} & Aktif & 59 \\
\hline & & Pasif & 41 \\
\hline & & Jumlah & 100 \\
\hline \multirow[t]{3}{*}{2} & \multirow{3}{*}{$\begin{array}{l}\text { Mengingatkan } \\
\text { teman ketika } \\
\text { membuang } \\
\text { sampah } \\
\text { sembarangan }\end{array}$} & Aktif & 51 \\
\hline & & Pasif & 49 \\
\hline & & Jumlah & 100 \\
\hline
\end{tabular}


Pada Tabel 5, menunjukkan partisipasi masyarakat dalam menggunakan ulang sampah styrofoam dan botol plastik mineral masih terbilang pasif. Dimana sebanyak 63\% masyarakat belum memanfaatkan styrofoam bekas menjadi dasar menempel catatan kegiatan atau dimanfaatkan untuk keperluan yang lain. Sebagian besar masyarakat yang tidak memanfaatkan botol minum plastik bekas dan styrofoam bekas pada kegiatan sehari-hari di lingkungan disebabkan tidak terpikirkan dan tidak terbiasa dalam memanfaatkan sampah bekas yang masih dapat digunakan untuk keperluan kampus atau organisasi. Hal ini dikarenakan minimnya pengetahuan mengenai dampak pengelolaan sampah yang buruk dan pembuangan sampah dilakukan secara spontanitas tanpa memikirkan akhir dari sampah tersebut. Disamping itu, bagi masyarakat, pemanfaatan kembali sampah bekas dinilai kurang estetik, sehingga masyarakat cenderung memilih untuk membeli karena murah dan lebih praktis.

Seperti yang diungkapkan oleh Sartika, dkk. (2021) bahwa masyarakat memiliki pola hidup serba praktis. Ditunjukkan pada tingginya pemakaian pembungkus makanan dan minuman.

Tabel 5.

Partisipasi Masyarakat dalam Kegiatan Reuse

\begin{tabular}{|c|c|c|c|}
\hline No & Pernyataan & Partisipasi & $\begin{array}{c}\text { Res- } \\
\text { ponden } \\
(\%)\end{array}$ \\
\hline \multirow[t]{3}{*}{1} & \multirow{3}{*}{$\begin{array}{l}\text { Menggunakan } \\
\text { bahan kertas } \\
\text { yang sudah } \\
\text { tidak terpakai } \\
\text { untuk } \\
\text { pemanfaatan } \\
\text { lainnya }\end{array}$} & Aktif & 38 \\
\hline & & Pasif & 62 \\
\hline & & Jumlah & 100 \\
\hline \multirow[t]{3}{*}{2} & \multirow{3}{*}{$\begin{array}{l}\text { Memanfaatkan } \\
\text { styrofoam bekas } \\
\text { yang masih } \\
\text { dapat digunakan } \\
\text { wadah atau } \\
\text { untuk keperluan } \\
\text { yang lain }\end{array}$} & Aktif & 37 \\
\hline & & Pasif & 63 \\
\hline & & Jumlah & 100 \\
\hline
\end{tabular}

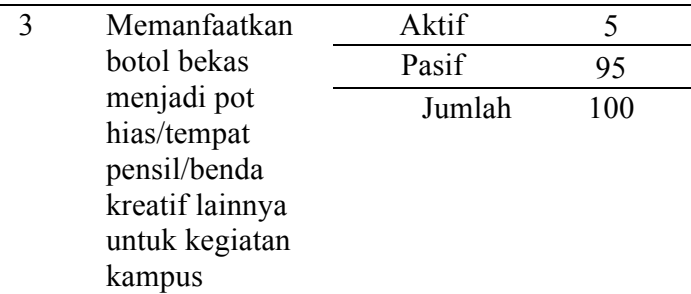

\section{Analisis Faktor-Faktor yang Mempengaruhi Partisipasi Masyarakat terkait Pengelolaan Sampah}

\section{Kegiatan Reduce}

Untuk mengetahui faktor yang membedakan terbentuknya partisipasi masyarakat secara aktif dan pasif dalam kegiatan reduce, dilakukan analisis diskriminan terhadap lima faktor (persepsi (X1), pengetahuan (X2), pengalaman (X3), komunikasi (X4), sarana (X5) pada setiap pernyataan. Hasil analisis berdasarkan pengujian dapat dilihat pada Tabel 6, dengan menunjukkan bahwa Wilk's Lamda sangat kecil dibandingkan $\alpha 5 \%$, maka diketahui bahwa fungsi diskriminan terbilang signifikan berdasarkan statistik.

Tabel 6.

Faktor-Faktor Mempengaruhi Partisipasi Masyarakat dalam Kegiatan Reduce

\begin{tabular}{lcc}
\hline Variabel & Sig. & Keterangan \\
\hline Komunikasi & 0,05 & $\begin{array}{c}\text { Berpengaruh } \\
\text { nyata }\end{array}$ \\
Eigenvalues & 0,399 & \\
Wilks' Lambda & 0,01 & \\
$Z$ score $=-5,240+0,450$ X4 & \\
\hline
\end{tabular}

Dimana pada persamaan Zscore menunjukkan semakin meningkatnya proses komunikasi tentang pengelolaan sampah melalui workshop/pelatihan, maka akan semakin meningkat pula partisipasi masyarakat dalam mengurangi sampah. Dalam hal ini, kampus sebagai wadah dimana masyarakat mencari ilmu, perlu memberikan komunikasi kepada masyarakat secara konsisten dan menyeluruh melalui media komunikasi secara verbal seperti pelatihan atau 
workshop, hingga memberikan dampak pada masyarakat sebagai penerima pesan tentang pengelolaan sampah ramah lingkungan. Pesan yang diterima dapat menjadi dasar pengetahuan untuk dipahami, hingga mempengaruhi masyarakat tersebut untuk berperilaku mengurangi sampahnya.

Hasil penelitian dari Santoso (2009) pun menunjukkan faktor-faktor yang berpengaruh signifikan terhadap peran serta masyarakat salah satunya adalah unsur komunikasi. Informasi yang diterima oleh individu kemudian diproses menjadi bentuk pengetahuan. Tingkat pengetahuan pada suatu titik di suatu waktu tertentu menunjukkan besarnya informasi yang dimiliki masih rendah tidak menyebabkan pengaruh terhadap orang-orang tertentu. Artinya tingkat informasi tersebut tidak mendorong suatu sistem yang berada dalam suatu individu untuk mengadopsinya. Tetapi, jika informasi bertambah luas sehingga melewati titik ambang tertentu, pengadopsian akan melaju sendiri dan memberi dorongan untuk kecepatan adopsi. Apabila anggota sistem pada suatu individu yang mengetahui inovasi baru mencapai 20\%-30\%, hal ini belum dapat mempengaruhi setiap individu secara luas untuk melakukan perubahan (Prastiwi, 2009).

\section{Kegiatan Memilah Sampah}

Hasil analisis berdasarkan pengujian dapat dilihat pada Tabel 7, dengan menunjukkan bahwa Wilk's Lamda sangat kecil dibandingkan $\alpha 5 \%$, maka diketahui bahwa fungsi diskriminan terbilang signifikan berdasarkan statistik. Hal ini menunjukkan bahwa rerata skor diskriminan pada dua kelompok partisipasi (partisipasi aktif dan partisipasi pasif) memiliki perbedaan secara signifikan.
Tabel 7.

Faktor yang Mempengaruhi Partisipasi

Masyarakat dalam Memilah Sampah

\begin{tabular}{|c|c|c|}
\hline Variabel & Sig. & Keterangan \\
\hline Pengalaman & 0,02 & $\begin{array}{l}\text { Berpengaruh } \\
\text { nyata }\end{array}$ \\
\hline Komunikasi & 0,01 & $\begin{array}{l}\text { Berpengaruh } \\
\text { nyata }\end{array}$ \\
\hline Sarana & 0,06 & $\begin{array}{l}\text { Berpengaruh } \\
\text { nyata }\end{array}$ \\
\hline Eigenvalues & 0,389 & \\
\hline Wilks' Lambda & 0,00 & \\
\hline \multicolumn{2}{|c|}{$\begin{array}{l}Z \text { score }=-6,359+0,812 X 3+ \\
0,708 X 4+0,344 X 5\end{array}$} & \\
\hline
\end{tabular}

Dimana pada persamaan Zscore menunjukkan semakin meningkatnya pengalaman, informasi/komunikasi dan dukungan sarana pemilahan akan mempengaruhi partisipasi masyarakat secara aktif dalam memilah sampahnya.

Hasil analisis ini sejalan dengan pendapat Rahayuningsih (2008) menyatakan terbentuknya sikap positif masyarakat terhadap upaya pengelolaan sampah terjadi apabila adanya pengaruh pengalaman, kebudayaan, pengaruh orang yang dihormati, dan media massa. Dengan adanya pengalaman, informasi/komunikasi maupun bentuk edukasi lingkungan lainnya, masyarakat dapat mengetahui dampak-dampak secara langsung maupun tidak langsung dan dampak jangka pendek dan panjang dalam pengelolaan sampah, sehingga dapat membentuk pola pikir dan sikap positif.

Minimnya pengalaman dalam menghadapi suatu objek, menjadikan seseorang mengartikan suatu objek tersebut berdasarkan asumsi semata, sehingga ketidakterbiasaan/minimnya pengalaman terdahulu seseorang terhadap sesuatu, akan sulit untuk melakukan hal tersebut.

Faktor internal yang dimiliki oleh masyarakat dalam memilah sampah tidak dapat berjalan baik ketika tidak adanya faktor pendukung dari lingkungan/eksternalnya berupa sarana. Sarana-prasarana yang memadai, tentu 
berdampak pada terwujudnya kebersihan dan kenyamanan lingkungan. Umumnya, saranaprasarana kebersihan mencakup beberapa fasilitas, diantaranya sampah pilah, tempat sampah sementara, serta armada dan peralatan kerja (Kastaman dan Kramadibrata, 2007) dalam (Riduan, 2012).

Hasil penelitian menunjukan sebanyak $69 \%$ masyarakat masih berpartisipasi secara pasif dalam memilah sampah. Masyarakat menyatakan bahwa tidak semua di sekitar gedung perkuliahan tersedia tempat pemilah sampah dan belum terlihat jelas tulisan organik dan anorganik. Seharusnya hal ini diperhatikan, menurut Kastaman dan Kramadibrata (2007) dalam Riduan (2012) menyatakan bahwa saranaprasarana memiliki peran penting dalam pengelolaan sampah. Tanpa adanya sarana akan menghambat masyarakat berpartisipasi.

Penyediaan sarana harus ditunjang secara menyeluruh. Seperti hasil penelitian Bebassari (1996) dalam Murdeani (2006) membuktikan bahwa partisipasi masyarakat dalam pemilahan sampah tidak hanya didukung ketersediaan tempat pemilahan sampah, namun perlu didukung pula dengan adanya sarana memadai secara menyeluruh, seperti gerobak terpisah atau jadwal pengangkutan berbeda. Menurut Rahmayanti (2016) diperlukan penyediaan fasilitas Tempat Sampah Terpilah (TST) untuk mendorong perilaku masyarakat yang bersih, yakni dengan menempatkan sampah berdasarkan jenisnya. Adanya TST, sampah dapat dijadikan sebagai komoditi ekonomi baru, yakni dapat memberi lapangan kerja dan pendapatan baru. Sampah organik dapat diolah menjadi materi energi (biogas), pupuk organik baik padat maupun cair.
Menurut Rizky, dkk. (2019), kebiasaan membuang sampah tanpa pemilahan menjadikan lokasi pengolahan sampah lebih sempit. Oleh karena itu, diperlukan pengelolaan sampah terintegrasi seperti bank sampah. Bank sampah merupakan salah satu strategi penerapan 3R (reduse, reuse, dan recycle). Menurut Rejeki, dkk., (2016) bahwa pada prinsipnya, bank sampah mengajak masyarakat untuk memilah sampah. Masyarakat mengumpulkan dan memilah sampah, lalu menukarnya dengan uang atau barang berharga yang dapat ditabung. Hasil pengumpulan dan pemilahan sampah akan dialihkan pada tempat kerajinan dari sampah maupun tempat pengepul sampah (Rizky, dkk., 2019).

Kegiatan Membuang Sampah

Hasil analisis berdasarkan pengujian dapat dilihat pada Tabel 8, dengan menunjukkan bahwa Wilk's Lamda sangat kecil dibandingkan $\alpha 5 \%$, maka diketahui bahwa fungsi diskriminan terbilang signifikan berdasarkan statistik. Hal ini menunjukkan bahwa rerata skor diskriminan pada dua kelompok partisipasi (partisipasi aktif dan partisipasi pasif) memiliki perbedaan secara signifikan.

Tabel 8.

Faktor-faktor Mempengaruhi Partisipasi Masyarakat terkait Pembuangan Sampah di Tempatnya

\begin{tabular}{lcc}
\hline Variabel & Sig. & Keterangan \\
\hline Persepsi & 0,03 & $\begin{array}{c}\text { Berpengaruh } \\
\text { nyata } \\
\text { Perpengaruh } \\
\text { nyata }\end{array}$ \\
Eigenvalues & 0,00 & \\
Wilks' Lambda & 0,388 & 0,01 \\
$\begin{array}{l}Z \text { score }=-6,517+0,679 \mathrm{X} 1+ \\
1,061 \mathrm{X} 3\end{array}$ & \\
\hline
\end{tabular}

Dimana pada persamaan Zscore menunjukkan ketika persepsi dan pengalaman masyarakat dalam membuang sampah pada tempatnya semakin meningkat, maka akan 
meningkatkan pula partisipasi masyarakat secara aktif dalam membuang sampah pada tempatnya.

Harihanto (2001) dalam Asmara dan Suhirman (2012) mengungkapkan bahwa diperlukan persepsi yang benar terhadap suatu objek karena persepsi adalah dasar pembentukkan sikap dan perilaku. Persepsi yang keliru dapat memunculkan perilaku yang keliru pula. Faktor internal lainnya selain persepsi, yakni pengalaman. Pengalaman berpengaruh dalam partisipasi masyarakat secara aktif atau pasif dalam membuang sampah pada tempatnya.

\section{Kegiatan Reuse}

Hasil analisis berdasarkan pengujian dapat dilihat pada Tabel 9, dengan menunjukkan bahwa Wilk's Lamda sangat kecil dibandingkan $\alpha 5 \%$, maka diketahui bahwa fungsi diskriminan terbilang signifikan berdasarkan statistik. Hal ini menunjukkan bahwa rata-rata skor kedua kelompok partisipasi (partisipasi aktif dan partisipasi pasif) memiliki perbedaan secara signifikan. Persamaan Zscore menunjukkan ketika komunikasi melalui media seminar/workshop ataupun media informasi lain yang dilakukan secara dua arah sering dilakukan secara intens maka partisipasi aktif masyarakat dalam kegiatan reuse semakin meningkat. Menurut Roni (2013) yang dapat mempengaruhi kesadaran seseorang terhadap lingkungan adalah komunikasi lembaga terhadap masyarakat. Dalam hal ini, diperlukan komunikasi dua arah, tidak hanya antara kampus sebagai pemegang manajemen sampah keseluruhan sebagai kebijakan, tetapi perlunya komunikasi antara petugas sampah secara langsung yang biasa bekerja di lapangan. Dengan begitu, pengelola sampah tahu apa yang diinginkan oleh masyarakat dan sebaliknya masyarakat tahu apa yang diharapkankan pengelola sampah, sehingga tidak ada lagi tindakan yang saling menyalahkan.

Menurut Sartika, dkk. (2021)

bahwa pengelolaan sampah harus dilakukan secara sinergi antara pemerintah desa dengan masyarakat demi mencapai lingkungan desa yang bersih dan nyaman. Selain itu, kerjasama dari tokoh masyarakat juga diperlukan untuk mendukung pengelolaan sampah.

Mengacu kepada penanganan sampah di negara Finlandia yang menjadi salah satu negara tersukses dalam menimilisasi limbah rumah tangga per kapita (Koda 2012a). Pengelolaan sampah di Finlandia dibangun dengan cara menekankan pentingnya komunikasi lingkungan dan membangun eco-center, yaitu tempat pembuangan akhir sampah (TPA) namun dijadikan pusat di mana siapa pun bisa belajar tentang isu-isu lingkungan secara gratis dan dalam banyak kasus dapat membeli item daur ulang untuk digunakan (Koda 2012b). Pada penelitian ini, partisipasi dalam kegiatan reuse di lingkup kampus menjadi hal yang masih sulit dan belum wajar dilakukan. Hasil analisis secara diskriminan menghasilkan bahwa faktor komunikasi menjadi faktor yang berpengaruh pada partisipasi masyarakat secara aktif ataupun pasif dalam melakukan kegiatan reuse. Dimana proses komunikasi dua arah secara intens akan mempengaruhi masyarakat berpartisipasi secara aktif dalam kegiatan reuse.

Tabel 9.

Faktor yang Mempengaruhi Partisipasi Masyarakat dalam Kegiatan Reuse

\begin{tabular}{lcc}
\hline Variabel & Sig. & Keterangan \\
\hline Komunikasi & 0,03 & Berpengaruh nyata \\
Eigenvalues & 0,368 & \\
Wilks' Lambda & 0,03 & \\
Z score $=-3,397+1,008 \times 4$ & \\
\hline
\end{tabular}

Sumber: Data Primer (2016) 


Dengan adanya $\begin{array}{r}\text { berbagai } \\ \text { dapat }\end{array}$
pelatihan bantu
meningkatkan persepsi dan partisipasi
masyarakat terutama kegiatan reuse.
Adapun contoh-contoh pelatihan yang
dapat diterapkan, seperti sosialisasi
mengenai sampah dan manfaat dari
sampah. Pelatihan mengenai
pemanfaatan sampah anorganik menjadi
suatu benda yang dapat digunakan
dalam kehidupan sehari-hari maupun
komersil, pelatihan mengenai
pemanfaatan sampah organik melalui
pembuatan kompos dari biopori,
takakura, dan lain-lain (Sartika, dkk.,
2021).

\section{Kesimpulan dan Saran}

Dari keempat kegiatan pengelolaan sampah, menunjukan bahwa seluruh masyarakat telah berpatisipasi dalam setiap jenis kegiatan pengelolaan sampah. Dimana rata-rata masyarakat berpartisipasi aktif dalam kegiatan membuang sampah (55\%). Sedangkan, partisipasi masyarakat cenderung pasif pada kegiatan reduce, memilah sampah dan kegiatan reuse. Bahkan kegiatan reuse masih dikatakan sulit dilakukan di lingkungan tempat tinggal oleh masyarakat. Faktor yang membedakan terbentuknya partisipasi masyarakat secara aktif dan pasif dalam pengelolaan sampah di lingkungan tempat tinggal adalah faktor persepsi, pengalaman, komunikasi, dan sarana. Berdasarkan klasifikasi partisipasi dalam empat jenis kegiatan pengelolaan sampah menghasilkan faktor yang berbeda.

\section{DAFTAR PUSTAKA}

Alfiandra. 2008. Kajian Partisipasi Masyarakat yang Melakukan Pengelolaan Persampahan $3 \mathrm{R}$ di Kelurahan Ngaliyan dan Kalipancur Kota Semarang. Tesis.
Amaranti, R., Achiraeniwati, E., As'ad, N., Nasution, A., Satori, M. 2016. Pendampingan Masyarakat dalam Pengolahan Sampah Organik Rumah Tangga untuk Mendukung Program Urban Farming. Ethos (Jurnal Penelitian dan Pengabdian Masyarakat), vol. 4, No.2: 283-290.

Asmara, Y dan Suhirman. 2012.

Persepsi Dan Sikap Masyarakat Terhadap Kegiatan Ekowisata Kampung Cikidang Desa Langensari Kecamatan Lembang, Kabupaten Bandung Barat. Jurnal Perencanaan Wilayah dan Kota A SAPPK Vol. 1 No. 2 Hal.568-576. Sekolah Arsitektur, Perencanaan dan Pengembangan Kebijakan ITB. Bandung.

Budiasih, Kun Sri. 2010. Pemilahan Sampah sebagai Upaya Pengelolaan Sampah yang Baik. Makalah Program Pengorganisasian dan Pengembangan Masyarakat. Hal: 1-10. Fakultas MIPA, Jurusan Pendidikan Kimia, Universitas Negeri Yogyakarta.

Damanhuri, E dan Padmi, T. 2010. Pengelolaan Sampah. Diktat Kuliah TL-3104 (Bagian I): 1-97, Program Studi Teknik Lingkungan, Fakultas Teknik Sipil dan Lingkungan, Institut Teknologi Bandung.

Dermawan, Lahming, Ahsan, M. Mandra, S. 2018. Kajian Strategi Pengelolaan Sampah. UNM Environmental Journals, Vol. 1, No. 3: 86-90.

Fadhilah, A., Sugianto, H., Hadi, K., Firmandhani, S.W., Murtini, T.W., Pandelaki, E.E. 2011. Kajian Pengelolaan Sampah Kampus Jurusan Arsitektur Fakultas Teknik Universitas Diponegoro. ISSN: 0853-2877. Modul Vol. 11 No. 2 Hal.62-71 Agustus 2011.

Fandoko, G. T., \& Anityasari, M. 2012. Evaluasi Life Cycle Management 
(LCM) Pada Rencana Program Transportasi Massal Untuk Mendukung Eco Campus ITS. Jurnal Teknik POMITS No.1, Vol.I, 1-6.

Ghozali, Imam. 2016. Aplikasi Analisis MultivarieteDengan Program IBM SPSS 23. Cetakan VIII, Semarang: Badan Penerbit Universitas Diponegoro

Harihanto. 2001. Persepsi Masyarakat Terhadap Air Sungai, Lingkungan dan Pembangunan 24 (3): 171-186

Ife Jim dan Tesoriero. 2008. Community Development: Alternatif Pengembangan Masyarakat di Era Globalisasi. Edisi Bahasa Indonesia diterbitkan Oleh Pustaka Pelajar. Cetakan I. Celeban Timur UH III/548 Yogyakarta.

Koda, S. 2012a. The Motivation for Proenvironmental Behavior: Household Waste Disposal Towards Environmentally Friendly Daily Life: Case Studies in Finland. Journal of Educational and Social Research, 2(1), 191-198. doi: 10.5901/jesr.2012.02.01.191

Koda, S. 2012b. Theoretical Approach to the Collaborative Environmental Activities: Household Waste Disposal towards Environmentally Friendly Daily Life. International Journal of Humanities and Social Science, 2(6), 104-110 Retrieved from

http://www.ijhssnet.com/journals/V ol 2 No 6 Special_Issue March 2 $0 \overline{12} / \overline{8} \cdot \mathrm{pdf}$

Maulina, A., S. Identifikasi Partisipasi Masyarakat Dalam Pemilahan Sampah Di Kecamatan Cimahi Utara Serta Faktor yang Mempengaruhinya. Jurnal Perencanaan Wilayah dan Kota, Vol. 23 No. 3, Desember 2012 hlm. 177-196.

Pemerintah Desa Cinunuk. 2016. Desa Cinunuk. https://cinunuk.desa.id/artikel/

2016/8/26/wilayah-desa-cinunuk.

Diakses pada 8 Mei 2021.

Prastiwi, Wiwik. 2009. Implementasi Konsep $3 R$ dalam Pengolahan Sampah Perkotaan Berbasis Masyarakat (Studi Kasus di Kelurahan Tamansari Kota Bandung). Tesis. Program Studi Magister Ilmu Lingkungan, Program Pasca Sarjana, Kosentrasi Manajemen Sumber Daya Alam \& Lingkungan Hidup. Bandung: Universitas Padjadjaran.

Rahayuningsih. 2008. Psikologi Umum 2. Diakses melalui [http://www.statf.undip.ac.id] pada tanggal 01 Maret 2016.

Rahmayanti, Henita. 2016. Kosep Pemahama dan Teknologi Pengelolaan Sampah di Rumah Susun Sewa. Ethos (Jurnal Penelitian dan Pengabdian Masyarakat). Vol. 4 (1): 35 - 40.

Riduan, Akhmad. 2012. Partisipasi Masyarakat Dalam Pengelolaan Sampah di Bantaran Sungai Kali Nagara Kabupaten Hulu Sungai Utara. Jurnal Socioscientia Kopertis Wilayah XI Kalimantan, Vol. 4, No.2, Hal. 187-196.

Rizky, A.A., Rozalena, A., Muthmainnah. 2019. Pelatihan Pengelolaan Bank Sampah Desa Sumbersari Kec. Ciparay, Kab. Bandung. Ethos: jurnal Penelitian dan Pengabdian kepada Masyarakat, Vol. 8, No.1: 78-88.

Rejeki, Y.S., Dzikron, M., Nugraha, Shofi, D., Chaznin, R.M., Khairunnas, J., Ulfah, H.S., Saefurrohman, A. 2016. Peningkatan Peran Serta Masyarakat dalam Pengurangan Timbulan Sampah. Ethos (Jurnal Penelitian dan Pengabdian Masyarakat), Vol. 4, No. 1: 161-170.

Roni, Zam. 2013. Menyampah Akibat Kurangnya Kesadaran Sehingga 
Perlu Diubah Menjadi Kebiasaan yang Peduli Lingkungan. Tugas Artikel Ilmiah (1-8).

Santoso, S. 2009. Peran Serta Masyarakat dalam Perbaikan Lingkungan. Tesis. Program Studi Magister Ilmu Lingkungan, Program Pasca Sarjana, Kosentrasi Manajemen Sumber Daya Alam \& Lingkungan Hidup. Bandung: Universitas Padjadjaran.

Saribanon, Nonon, dan Pranawa, S. 2008. Strategi dan Mekanisme Perencanaan Sosial Partisipatif dalam Pengelolaan Sampah Berbasis Masyarakat di DKI
Jakarta. Jurnal Poelitik, Vol. 4, No.2: 337-353.

Sartika, E., Murniati, S., Karnisah, I. 2021. Pemberdayaan Masyarakat melalui Pengelolaan Sampah di Desa Sukamenak. Ethos: Jurnal Penelitian dan Pengabdian kepada Masyarakat, Vol. 9, No.1: 98-106.

Suprapto. 2005. Danpak Masalah Sampah Terhadap Kesehatan Masyarakat. Jurnal Mutiara Kesehatan Indonesia. Vol. 1 No. 2: 1-4 